\title{
飲食店でとられる着座姿勢の特徵 CHARACTERISTICS OF SITTING POSTURES IN EATING AND DRINKING SPACES
}

\author{
小林茂雄*, 村中 美奈子**
}

\author{
Shigeo KOBAYASHI and Minako MURANAKA
}

\begin{abstract}
In this research, people's sitting postures in various types of eating and drinking spaces were observed, and their characteristics and related factors were analyzed. The principle results are summarized as follows.

1. More people tended to bend forward in fast-food restaurants, and more people tended to bend backward in izakaya (Japanese-style bars). Men tended to bend forward more than women in izakaya and restaurants, on the other hand, women tended to bend forward more than men in cafes.

2. Younger people tended to bend forward in fast-food restaurants more than older people, and older people tended to bend forward in izakaya more than younger people.

3. People in conversation tended to put their elbows on the tables more than people who were not talking, and people who were not eating tended to put their elbows on the tables more than people who were eating.

4. People in bright spaces tended to bend forward more than people in dark spaces, and people in noisy spaces tended to put their elbows on the tables more than people in quiet spaces.
\end{abstract}

Keywords: sitting posture, eating and drinking place, bend forward, put one's elbow on the table, cross one's legs, observational investigation

着座姿勢、飲食店、前屈み、肘をつく、足を組む、観察調査

\section{1. 研究の背景と目的}

人が着座するときの姿勢は、滞在目的、座る対象の形状、身体的な特 徵に強く依存するが、そ机以外にも対人的な属性や空間の特徴なぞに左 右されやすいと考えられる。本研究では、都市生活において着座する 人々がどのような姿勢をとっているかを調査し、その特徴と関わる要因 を示そうとするものである。対象とする空間は、多くの人々が日常的に 利用する場所の中で、一定時間以上着座することが多く、空間のバリ エーションが比較的あり、また着座行為を観察しやすい場所として、飲 食店を取り上げることとした。

着座姿勢に関する既往研究として、建物内の一箇所の休憩所で利用者 の行動を観察したもの1)があり、椅子よりもベンチの方が後傾する割合 が高いことや、高年層よりも若年層の方が足を組む割合が高いことが示 されている。また、着座姿勢に与える身体の柔軟性 ${ }^{2}$ や椅子の形状 ${ }^{3}$ な どについて検討したものや、オフィスでの作業姿勢と疲労感の関係を調 ベたり ${ }^{4)}$ 、劇場や電車シートに着座する人々の姿勢の経時変化を調べた りしたもの5)もる。これらの研究では、基本的に身体の疲労を回避す る姿勢のとり方という点に着目している。姿勢に与える身体的特徵や椅 子の形状は扱っているものの、その他の環境要因については積極的に 扱っているわけではない。飲食時の着座姿勢については、住宅でのテー ブルの高さやテレビの有無などを姿勢の悪さを促す要因として取り上げ
たものがある ${ }^{6}$ が、着座姿勢の特徴や傾向を示したり、都市空間での飲 食の場を対象としたりしたものはない。一方、筆者らのこれまでの研究 では、飲食店や実験室において、照明や音環境が会話者の行為や姿勢の 傾きに与える影響を実験的に検討してきた ${ }^{7 \sim 11)}$ 。その結果、照度と姿勢 との関係には性別による違いがみられ、女性は低照度ほど、男性は高照 度ほど前傾姿勢をとりやすいことなどの結果を得ている。ただし既往研 究では照度や音量のレベルを極端に変えた実験条件を設定しているた め、日常的にとられる姿勢の特徵とは異なる可能性がある。

本研究の特徵は、飲食店を実際に利用している着座者の姿勢を観察 し、その特徵を示すことと、姿勢のとり方に与える利用者の属性や環境 的条件などの影響を探ることにある。

\section{2. 調査概要}

首都圈の屋内空間で営業中の飲食店125店舗を調査対象とした。内訳 は、カフェ 54 店舗、ファストフード 26 店舗、レストラン 30 店舗、居酒 屋15店舗である注1)。図1に店舗の例を示す。対象とした店舗の条件は、 椅子に座る夕イプであり床座式ではないこと、個室化されていたり照度 が低すぎたり $(10$ ( $\mathrm{lx}$ ) 未満)することなく利用者の姿勢が把握できるこ と、気軽に利用できる店舗で高級な飲食店ではないこと注2)とした。椅 子の特徵によって姿勢が極端に強制される事例は避けるため、座面高さ
* 武蔵工業大学工学部建築学科 准教授 ·博士 (工学)

** (有)田中事務所 修士(工学)
Assoc. Prof., Dept. of Architecture, Musashi Institute of Technology, Dr. Eng. Group Tanaka, M. Eng. 
が30〜 60cmで机上面との高さの差が25〜35cmのものを対象とし、サ イズや形状が特殊であったり身体が沈み込んだりするような椅子も扱わ ないこととした。

調査は2007年4月～9月の 12 時〜 24時の間に、2名の調査者で行なつ た。観察対象者は、調査者の座席周辺で姿勢や動作が観察可能な者と し、1店舗につき 10 名程度とした。座席に着いた直後の 10 分間は対象 としていない。得られたサンプルは合計で1208名 (男性564名、女性636 名、性別不明8名)である。

店舗内部の調査項目としては、机上面などの主要な照度、音環境、椅 子の素材及び形状、利用者の周辺からの見えやすさなどがある。利用者 に関する調査項目は、着座時の姿勢の他に、性別、年代、座席の位置、 とられる行為である。これらの項目は、予備調査の結果を基に、姿勢に 影響を与えていると推測されたものを選定した。利用者の性別や年代な どの属性は、調査者 2 名の目視によって推測したものである。判断でき ない場合は「不明」とした。姿勢は、足を組んでいるか（「足組み」と 表記)、テーブルに肘をついているか(「肘つき」と表記)、体の傾きが 前傾か垂直か後傾か (体の傾き) の3点に着目した。図2にこれらの模 式図を示す注3)。何机も、各々の利用者を約 10 分間観察した上で、足組 みと肘つきについては過半数の時間その動作をしているかどうかで、体 の傾きについては最も長くとっている状態で判断した。ただし、体の傾 きを頻繁に変える着座者で、主な傾きを判断できない場合は「不定」と することとした。また観察中に特定の行為を過半数の時間以上していれ ば、その行為を記録することとした。具体的に多かった行為は、会話、 食事、勉強や読書などの作業(「勉強」と表記)、携帯電話の操作である。

\section{3. 結果と考察}

\section{3-1. 姿勢のとり方の全体的傾向}

表1に、観察調査結果の概要を店舗種別ごとに示す。表より、足を組 んでいる着座者は全体で24\%と約1/4であり、肘をついている着座者は 35\% と約 1/3であることが分かる。体の傾きは前傾が43\%、垂直が $34 \%$ 、 後傾が $19 \%$ と、前傾が最も多い。表 2 に、着座時の足組み、肘つき、体 の傾きのクロス集計結果を示す。足を組む人は組まない人よりも後傾姿 勢をとる比率が高く、肘をつく人はつかない人よりも前傾姿勢をとる比 率が高くなっている。これらは、足組みと肘つきの動作をとるときの体 の保ちやすさに起因しているものと考えられる。また、足を組まない人 は組む人よりも、肘をつく比率がやや高くなっているが、顕著な差では ない。

表 3 に、足組み、肘つき、体の傾きと、各調査項目との $\chi$ 二乗検定結 果 (p值) を示す。表より、店舗種別は、姿勢のどの項目においても有意 差が認められている。表1より、カフェでは足を組む着座者の比率が $28 \%$ 、肘をつく比率が $39 \%$ 、 、 種類の店舗種別の中で最も高い。体の傾 きは、ファストフードで前傾の比率が、居酒屋で後傾の比率が高いとい う特徴がある。これらの要因について単純に特定することはできない が、各々の店舗での飲食スタイルが関係しているのではないかと推測で

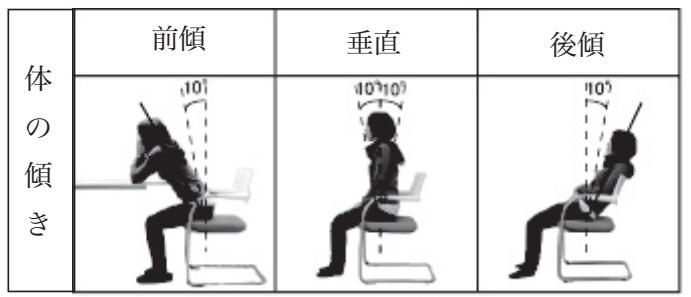

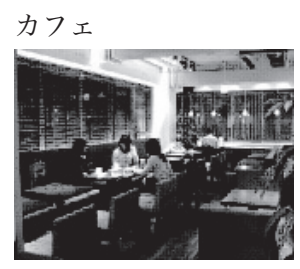

BEANUS CAFE新宿店

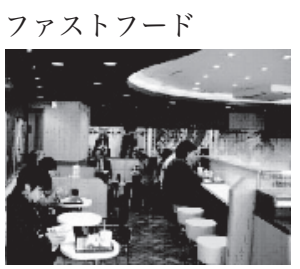

マクドナルド大岡山店

図 1 観察調査場所の例

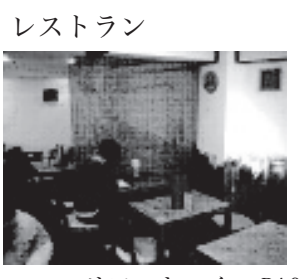

リアンキッチン $\mathrm{PAO}$
居酒屋

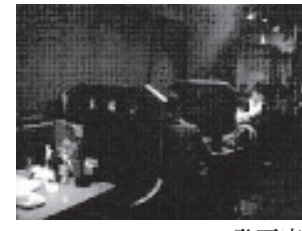

NIJYUMARU登戸店

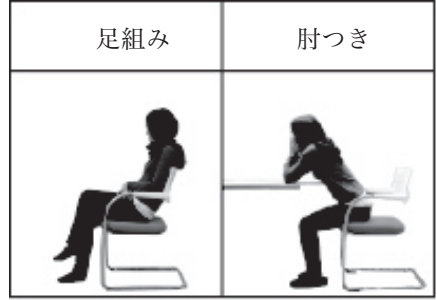

図2姿勢の分類模式図

表 1 観察調査結果 (人)

\begin{tabular}{|c|c|c|c|c|c|c|c|c|c|c|c|c|c|c|c|c|c|c|c|c|c|c|c|c|c|c|c|c|c|c|c|c|c|}
\hline \multirow{4}{*}{\multicolumn{2}{|c|}{$\begin{array}{l}\text { 店舗種別 } \\
\text { (占埔数) }\end{array}$}} & \multicolumn{4}{|c|}{ 時間带 } & \multicolumn{2}{|c|}{ 性別 } & \multicolumn{6}{|c|}{ 年代 } & \multicolumn{13}{|c|}{ 姿勢 } & \multicolumn{3}{|c|}{ 行為 } & \multicolumn{4}{|c|}{ 周囲からの見えや寸さ } \\
\hline & & \multirow{3}{*}{$\begin{array}{c}12-17 \\
\text { 時 }\end{array}$} & \multirow{3}{*}{\multicolumn{2}{|c|}{$\begin{array}{c}17-21 \\
\text { 時 }\end{array}$}} & \multirow{3}{*}{$\begin{array}{c}21-24 \\
\text { 時 }\end{array}$} & \multirow{3}{*}{ 男 } & \multirow{3}{*}{ 女 } & \multirow{3}{*}{ 10代 } & \multirow{3}{*}{ 20代 } & \multirow{3}{*}{ 30代 } & \multirow{3}{*}{ 40代 } & \multirow{3}{*}{$\begin{array}{l}50 \text { 代 } \\
\text { 以上 }\end{array}$} & \multirow{3}{*}{ 不明 } & \multirow{2}{*}{\multicolumn{2}{|c|}{ 足組み }} & \multirow{2}{*}{\multicolumn{2}{|c|}{ 肘つき }} & \multirow{2}{*}{\multicolumn{9}{|c|}{\begin{tabular}{l|l}
\multicolumn{2}{|c|}{ 体の傾き } \\
垂直 & 後傾 \\
\end{tabular}}} & \multirow{3}{*}{ 会話| } & & & & & & \\
\hline & & & & & & & & & & & & & & & & & & & & & & & & & & & & 食事兔 & 觔強携武 & 带 見 & 見え ど & ち5 & 見え \\
\hline & & & & & & & & & & & & & & 人数 & 比率 & 人数 & 比率 & 人数 & \begin{tabular}{|l|l|} 
女 & 比率
\end{tabular} & 人娄 & 数 & 北率 & 人数 & \begin{tabular}{|l|l|l|l} 
乘 \\
\end{tabular} & 人数 & 比率 & & & & & & & \\
\hline カフェ (54 & & 140 & 347 & & 40 & \begin{tabular}{l|l|l}
207 & 32 \\
$r$
\end{tabular} & 20 & 54 & 226 & 107 & 75 & 55 & 10 & 147 & 0.28 & 207 & 0.39 & 224 & 0.43 & 169 & & 0.32 & 100 & 0.19 & 34 & 0.06 & 310 & 173 & 120 & 47 & 236 & 177 & 114 \\
\hline $\begin{array}{l}\text { ファストフー } \\
(26) \\
\end{array}$ & & 68 & 147 & & 31 & \begin{tabular}{l|l}
142 & 10 \\
\end{tabular} & \begin{tabular}{l|l|}
02 & 2 \\
\end{tabular} & 100 & 62 & 41 & 25 & 16 & 2 & 51 & 0.21 & 78 & 0.32 & 123 & 0.50 & 77 & & .31 & 36 & 0.15 & 10 & 0.04 & \begin{tabular}{l|l}
137 & 1 \\
\end{tabular} & 115 & 63 & 13 & 132 & 78 & 36 \\
\hline レストラン & (30) & 30 & 160 & & 100 & \begin{tabular}{l|l}
134 & 15
\end{tabular} & 1 & 31 & 100 & 59 & 53 & 45 & 2 & 58 & 0.20 & 98 & 0.34 & 122 & 0.42 & 111 & & .38 & 55 & 0.19 & 2 & 0.01 & 190 & 179 & 21 & 17 & 128 & 87 & 75 \\
\hline 居酒屋（1 & & 11 & 75 & & 59 & 81 & 0 & 2 & 57 & 41 & 21 & 24 & 0 & 34 & 0.23 & 40 & 0.28 & 56 & 0.39 & 50 & & .34 & 39 & 0.27 & 0 & 0.00 & 116 & 98 & 1 & 5 & 68 & 39 & 38 \\
\hline 合計（125 & & 249 & 729 & & 230 & \begin{tabular}{l|l}
564 & 64
\end{tabular} & 41 & 187 & 445 & 248 & 174 & 140 & 14 & 290 & $\begin{array}{l}\text { 平均 } \\
0.24 \\
\end{array}$ & 423 & $\begin{array}{l}\text { 平均 } \\
0.35 \\
\end{array}$ & 525 & $\begin{array}{l}\text { 平均 } \\
0.43 \\
\end{array}$ & 3 & & 平均 & 230 & $\begin{array}{l}\text { 平均 } \\
0.19 \\
\end{array}$ & 46 & $\begin{array}{l}\text { 平均 } \\
0.04\end{array}$ & \begin{tabular}{l|l}
753 & 5
\end{tabular} & 565 & 205 & 92 & 564 & 381 & 263 \\
\hline & & & & & & & & & & 環境 & & & & & & & & & & & & 音環士 & & & & & & & 椅子 & の形状 & & & \\
\hline & & & & & & 照度 & {$[\mathrm{lx}]$} & & & & & & & & 照度 & 宽比 & & & & 主音源 & & & 刀音量 & & 辺会話 & 背も & たれの & 角度 & & 寸掛 & & 面の高 & \\
\hline 店舗種別 & & 机上 & & & & 顔吕 & & & & 周辺 & & & & 上面/周这 & & & 面/周辺 & & & & 屩房 & & & 聞き & \begin{tabular}{|l|l|} 
聞き \\
\end{tabular} & & & & & & & & \\
\hline & \begin{tabular}{|c|c|}
10 \\
-100 \\
\end{tabular} & \begin{tabular}{|c|}
100 \\
-250 \\
\end{tabular} & \begin{tabular}{r|r}
250 \\
-500 & 5 \\
\end{tabular} & 500- & $\begin{array}{r}10 \\
-100 \\
\end{array}$ & \begin{tabular}{|r|}
100 \\
-250 \\
\end{tabular} & \begin{tabular}{r|r}
250 & 5 \\
-500 & 5 \\
\end{tabular} & $500-$ & \begin{tabular}{c|c}
10 & 1 \\
-100 & -2 \\
\end{tabular} & \begin{tabular}{c|c}
100 & 2 \\
-250 & -5 \\
\end{tabular} & \begin{tabular}{c|c}
250 & 50 \\
-500 & 50 \\
\end{tabular} & $500-$ & \begin{tabular}{l|l|}
-0.99 \\
\end{tabular} & \begin{tabular}{|c|c|}
1.00 & 1 \\
-1.50 & 1 \\
\end{tabular} & $1.50-$ & -0.99 & \begin{tabular}{c|c}
1.00 & 1 \\
-1.50 & 1 \\
\end{tabular} & $1.50^{-1}$ & BGM & 会話 & $\begin{array}{c}\text { 設備 } \\
\text { 音 }\end{array}$ & 大 & 中 & \begin{tabular}{|l} 
取り \\
可
\end{tabular} & $\begin{array}{l}\text { 取り } \\
\text { 不可 }\end{array}$ & 以上 & 90度 & 無L & 有り & 無し & $\begin{array}{c}(\mathrm{cm}) \\
0\end{array}$ & $\begin{array}{c}(\mathrm{cm}) \\
(\mathrm{cos})\end{array}$ & $\begin{array}{c}500 \\
(\mathrm{~cm})\end{array}$ \\
\hline カフェ & 129 & 120 & 110 & 168 & 189 & 120 & 140 & 78 & 153 & \begin{tabular}{l|l}
126 & 1
\end{tabular} & \begin{tabular}{l|l}
120 & 1
\end{tabular} & 128 & 237 & 170 & 120 & 447 & 50 & 30 & 214 & 243 & 70 & \begin{tabular}{l|l}
20 & 3 \\
\end{tabular} & \begin{tabular}{l|l}
387 & 12
\end{tabular} & 177 & 350 & 381 & 111 & 35 & 407 & 120 & 20 & 310 & 197 \\
\hline $\begin{array}{l}\text { アアスト } \\
\text { フード }\end{array}$ & 0 & 10 & 159 & 77 & 0 & 28 & 160 & 58 & 10 & 10 & 149 & 77 & 71 & 155 & 20 & 145 & 71 & 30 & 118 & 117 & 11 & 89 & 92 & 206 & 40 & 129 & 100 & 17 & 216 & 30 & 0 & 135 & 111 \\
\hline レストラン & 40 & 100 & 40 & 110 & 80 & 70 & 100 & 40 & 90 & 60 & 40 & 100 & 110 & 110 & 70 & 200 & 50 & 40 & 70 & 158 & 62 & \begin{tabular}{l|l}
60 & 1 \\
\end{tabular} & \begin{tabular}{l|l}
160 & 70 \\
\end{tabular} & 120 & 170 & 107 & 147 & 36 & 270 & 20 & 20 & 247 & 23 \\
\hline 居酒屋 & 40 & 30 & 27 & 48 & 50 & 40 & 45 & 10 & 40 & 58 & 0 & 47 & 27 & 60 & 58 & 77 & 30 & 38 & 30 & 115 & 0 & \begin{tabular}{l|l}
27 & 1
\end{tabular} & 118 & 105 & 40 & 10 & 73 & 62 & 135 & 10 & 43 & 40 & 62 \\
\hline 合計 & 209 & 260 & 336 & 403 & 319 & 258 & 445 & 186 & 293 & 254 & 309 & 352 & 445 & 495 & 268 & 869 & 201 & 138 & 432 & 633 & 143 & \begin{tabular}{l|l}
196 & 7
\end{tabular} & \begin{tabular}{l|l|}
757 & 25 \\
\end{tabular} & 608 & 600 & 627 & 431 & 150 & 1028 & 180 & 83 & 732 & 393 \\
\hline
\end{tabular}


きる。例えば、カフェではソフトドリンク中心のためにテーブル上のス ペースをあまり必要としないこと、ファストフードでは手づかみで食事 をすることが多いこと、居酒屋ではアルコール中心の飲食であること、 などに起因する動作の差異があるのではないかと考えられる。

表3より、店舗種別以外の項目では、体の傾きについて有意差が認め られるものが多い。また表4に、姿勢のとり方と調査項目との関係につ いて、店舗種別ごとに $\chi$ 二乗検定を行なった結果を示している。以後こ れらの結果において、顕著な傾向が夕られた項目を中心にデー夕を示 す。

\section{3-2. 利用者の属性と姿勢の関係}

表3より、着座者の性別については体の傾きとに有意な関係が認めら れており、足組みや肘つきとでは有意な関係は認められなかった。そこ で図3に、体の傾きを利用者の性別ごとに示す。図より、どの店舗種別 でも男性は女性より後傾姿勢をとる比率が高く、女性は男性より垂直姿 勢をとる比率が高くなっていることが分かる。特に、居酒屋においてこ の傾向が強い。居酒屋では男性の方が、テーブルや椅子に体を預けるリ ラックスした姿勢をとりやすいものと考えられる。また、レストランと 居酒屋では男性の方が前傾姿勢の比率が高いのに対し、カフェでは女性 の方が前傾姿勢の比率が高くなっている。表4より、カフェと居酒屋に おいて、性別と体の傾きとに有意差が認められていることが分かる。ま たファストフードでは、性別による体の傾きの差はほとんどみられな かった。れらの結果から推測できることの一つに、性別によって店舗 種別でのコミュニケーションのとり方に違いがあるのではないかという

ことがある。例えば、居酒屋では女性より男性の方が活発 に会話していたり、カフェでは男性より女性の方が活発に 会話していたりするのではないかということである。本研 究では会話行為の有無のみを扱い、活発さなどの状態は調 査していないが、上記の傾向は調査者らによる観察時の印
象と一致するものであつた。

図4は、体の傾きを着座者の年代別に示している。ファストフードで は、30代以下の着座者は前傾姿勢の比率が高く、40代以上の着座者は 前傾姿勢の比率が低く垂直姿勢の比率が高いという傾向がみられる。 た、居酒屋では年齢層が高い着座者ほど前傾姿勢の比率が高くなってい る。これらのことから体の傾きは、年齢層との間に単純な関係があるわ けではなく、店舗種別によって傾き方が異なるということが分かる。前 傾姿勢をとる着座者はより活発にコミュニケーションをとることが多い と仮定すると、ファストフードでは若年層の方が、居酒屋では中高年層 の方が活発に会話していることになる。こうした傾向は調査者らの印象 とほぼ一致しているものでもある。ただし、着座者の年代と会話の有無 とのデー夕には直接関係はみられず、また会話の活発さについては本研 究で調査したわけではないため、そうした関係を明確に示せるわけでは ない。

表3より、着座者の年代は足組みとの関係も認められており、20代と 30 代の着座者が足を組む比率が他の年代よりも高いという特徵があっ た。この傾向は、既往研究の結果1)ともほぼ一致している。

\section{3-3. 利用者の行為と姿勢の関係}

図5は、会話行為と食事行為の有無と、肘つきとの関係を示している。 図より、会話をしている人の方がしていない人よりも、肘をつく比率が 高いことが分かる。これは会話をする際に、互いの顔を近づけることが 多いためではないかと考えられる。また、食事をしている人はしていな

表2 着座姿勢のクロス集計

\begin{tabular}{|c|c|c|c|c|c|c|c|c|c|c|c|c|c|c|c|c|c|}
\hline \multirow{3}{*}{\multicolumn{2}{|c|}{ 姿勢 }} & \multirow{3}{*}{ 人数 } & \multicolumn{4}{|c|}{ 足組及 } & \multicolumn{3}{|c|}{ 肘つき } & \multicolumn{8}{|c|}{ 体の傾き } \\
\hline & & & \multirow{2}{*}{\multicolumn{2}{|c|}{$\begin{array}{l}\text { 組む } \\
\text { 人数 比率 }\end{array}$}} & \multirow{2}{*}{\multicolumn{2}{|c|}{$\begin{array}{l}\text { 組まない } \\
\text { 人数]比率 }\end{array}$}} & \multicolumn{2}{|c|}{$x<$} & つかない & \multicolumn{2}{|c|}{ 前傾 } & \multicolumn{2}{|c|}{ 垂直 } & \multicolumn{2}{|c|}{ 後傾 } & \multicolumn{2}{|c|}{ 不定 } \\
\hline & & & & & & & 人数 & 比率 & 人数比 & 人娄 & 比率 & 人数 & 比率 & 人数 & 比率 & 人数 & 比率 \\
\hline \multirow{2}{*}{ 足組み } & 組む & 290 & & & & & 73 & 0.25 & \begin{tabular}{|l|l|}
217 & 0.7 \\
\end{tabular} & 103 & 0.36 & 75 & 0.26 & 106 & 0.37 & 6 & 0.02 \\
\hline & 組まない & 918 & & & & & \begin{tabular}{|l|l|}
350 \\
\end{tabular} & 0.38 & \begin{tabular}{|l|l|}
568 & 0.6 \\
\end{tabular} & 422 & 0.46 & 332 & 0.36 & 124 & 0.14 & 40 & 0.04 \\
\hline \multirow{2}{*}{ 时つき } & $2<$ & 423 & 73 & 0.17 & & & & & & 302 & 0.71 & \begin{tabular}{|l|}
89 \\
\end{tabular} & 0.21 & 16 & 0.04 & 16 & 0.04 \\
\hline & つかない & 785 & 217 & 0.28 & \begin{tabular}{|l|l}
568 & 0 \\
\end{tabular} & 0.72 & & & & 223 & 0.28 & 318 & 0.41 & 214 & 0.27 & 30 & 0.04 \\
\hline
\end{tabular}

表3 姿勢のとり方の $\chi$ 二乗検定結果 (p值)

\begin{tabular}{|c|c|c|c|c|c|c|c|c|c|c|c|c|c|c|c|c|c|c|c|c|}
\hline \multirow[b]{2}{*}{ 姿勢 } & \multirow[b]{2}{*}{$\begin{array}{l}\text { 店舗 } \\
\text { 種別 }\end{array}$} & \multirow[b]{2}{*}{ 時間带 } & \multirow[b]{2}{*}{ 性別 } & \multirow[b]{2}{*}{ 年代 } & \multicolumn{4}{|c|}{ 行為 } & \multirow{2}{*}{\begin{tabular}{|l} 
周柬か \\
万 \\
の見え \\
やすすさ
\end{tabular}} & \multicolumn{5}{|c|}{ 光環境 } & \multicolumn{3}{|c|}{ 音環境 } & \multicolumn{3}{|c|}{ 椅子の形状 } \\
\hline & & & & & 会話 & 食事 & 勉強 & $\begin{array}{l}\text { 势带 } \\
\text { 電話 }\end{array}$ & & $\begin{array}{l}\text { 机上面 } \\
\text { 照度 }\end{array}$ & \begin{tabular}{|l} 
顔面 \\
照菨
\end{tabular} & $\begin{array}{l}\text { 周辺 } \\
\text { 照度 }\end{array}$ & \begin{tabular}{|} 
机上面 \\
/周辺
\end{tabular} & $\begin{array}{l}\text { 顔面 } \\
\text { /周辺 }\end{array}$ & 主音源 & \begin{tabular}{|l} 
周辺 \\
音量
\end{tabular} & $\begin{array}{l}\text { 周辺 } \\
\text { 会話 }\end{array}$ & \begin{tabular}{|l} 
背もた \\
れ \\
の角度
\end{tabular} & $\begin{array}{c}\text { 时排 } \\
\text { の有無 }\end{array}$ & \begin{tabular}{|l} 
座面の \\
高さ
\end{tabular} \\
\hline 足組み & $\begin{array}{c}* \\
0.039\end{array}$ & 0.217 & 0.461 & $\begin{array}{c}* \\
0.024\end{array}$ & 0.119 & 0.224 & 0.564 & 0.816 & 0.205 & 0.403 & 0.119 & 0.285 & 0.401 & $\begin{array}{c}* \\
0.022\end{array}$ & 0.294 & $\begin{array}{c}* \\
0.041\end{array}$ & 0.107 & $\begin{array}{c}* \\
0.026\end{array}$ & 0.881 & 0.436 \\
\hline 时つき & $\begin{array}{c}* \\
0.028 \\
\end{array}$ & 0.736 & 0.398 & 0.154 & $\begin{array}{c}* * \\
0.001 \\
0.001\end{array}$ & $\begin{array}{c}* * \\
0.008 \\
\end{array}$ & 0.116 & $\begin{array}{c}* \\
0.046 \\
\end{array}$ & 0.758 & 0.842 & 0.747 & 0.451 & 0.133 & $\begin{array}{c}* \\
0.018 \\
\end{array}$ & 0.234 & \begin{tabular}{|c|c|}
$* *$ \\
0.009 \\
\end{tabular} & $\begin{array}{c}* * \\
0.023 \\
\end{array}$ & $\begin{array}{l}* * \\
0.000 \\
\end{array}$ & 0.996 & 0.955 \\
\hline 体の傾き & $\begin{array}{c}* * \\
0.000\end{array}$ & 0.114 & $\begin{array}{c}* * \\
0.002 \\
0.02\end{array}$ & $\begin{array}{c}* * \\
0.002 \\
0.02\end{array}$ & 0.203 & $\begin{array}{c}* * * \\
0.002\end{array}$ & $\begin{array}{c}* * \\
0.001\end{array}$ & $\begin{array}{c}* * \\
0.002 \\
\end{array}$ & \begin{tabular}{|c}
$*$ \\
0.039 \\
\end{tabular} & $\begin{array}{c}* * \\
0.000\end{array}$ & $\begin{array}{c}* * \\
0.000\end{array}$ & $\begin{array}{c}* * \\
0.000\end{array}$ & \begin{tabular}{|c}
$*$ \\
0.014 \\
\end{tabular} & $\begin{array}{c}* \\
0.018\end{array}$ & $\begin{array}{c}* \\
0.037\end{array}$ & \begin{tabular}{|c|}
$*$ \\
0.018 \\
\end{tabular} & $\begin{array}{c}* \\
0.034 \\
\end{array}$ & \begin{tabular}{|c|c|}
$* *$ \\
0.000 \\
\end{tabular} & $\begin{array}{c}* * \\
0.000 \\
0.00\end{array}$ & $\begin{array}{c}* * \\
0.002 \\
0.002\end{array}$ \\
\hline
\end{tabular}

表4 店舗種別ごとの姿勢の $\chi$ 二乗検定結果 ( $\mathrm{p}$ 值)

\begin{tabular}{|c|c|c|c|c|c|c|c|c|c|c|c|c|c|c|c|c|c|c|c|c|c|c|c|c|c|}
\hline \multirow{2}{*}{ 比較項目 } & \multirow{2}{*}{ 時間带 } & \multirow{2}{*}{\multicolumn{2}{|c|}{ 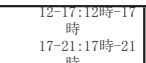 }} & \multirow{2}{*}{\multicolumn{3}{|c|}{ 性別 }} & \multirow{2}{*}{\multicolumn{2}{|c|}{ 年代 }} & \multirow{2}{*}{ 数字:年件 } & \multirow{2}{*}{\multicolumn{6}{|c|}{$\begin{array}{l}\text { 行為 } \\
\text { 食事 }\end{array}$}} & \multicolumn{6}{|c|}{ 育晾 $\times$ : 行為念L } & \multirow{2}{*}{\multicolumn{3}{|c|}{ 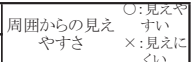 }} & \multirow{3}{*}{ 表記例 } \\
\hline & & & & & & & & & & & & & & & & & 勉強 & & & 携带なと & & & & & \\
\hline 姿勢 & $\begin{array}{l}\text { 足 } \\
\text { 組み }\end{array}$ & $\begin{array}{l}\text { 时 } \\
\text { つきき }\end{array}$ & \begin{tabular}{|l|} 
体の \\
傾き \\
\end{tabular} & $\begin{array}{l}\text { 足 } \\
\text { 組み }\end{array}$ & $\begin{array}{l}\text { 肘 } \\
\text { つき }\end{array}$ & 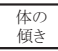 & $\begin{array}{c}\text { 足 } \\
\text { 組み } \\
\end{array}$ & $\begin{array}{l}\text { 肘 } \\
\text { つき }\end{array}$ & $\begin{array}{l}\text { 体の } \\
\text { 傾き } \\
\end{array}$ & $\begin{array}{c}\text { 足 } \\
\text { 組み } \\
\end{array}$ & $\begin{array}{l}\text { 肘 } \\
\text { つきき }\end{array}$ & $\begin{array}{l}\begin{array}{l}\text { 体 } \\
\text { 傾き }\end{array} \\
\end{array}$ & $\begin{array}{c}\text { 足 } \\
\text { 組み }\end{array}$ & $\begin{array}{l}\text { 时 } \\
\text { つき }\end{array}$ & $\begin{array}{l}\text { 体 } \circlearrowleft \\
\text { 傾き } \\
\end{array}$ & $\begin{array}{c}\text { 足 } \\
\text { 組み }\end{array}$ & $\begin{array}{l}\text { 时 } \\
\text { つき }\end{array}$ & $\begin{array}{l}\text { 体 }) \\
\text { 傾き } \\
\end{array}$ & $\begin{array}{c}\text { 足 } \\
\text { 組み }\end{array}$ & \begin{tabular}{|l|} 
时 \\
つき
\end{tabular} & \begin{tabular}{|l|} 
体の \\
傾き \\
\end{tabular} & $\begin{array}{c}\text { 是 } \\
\text { 組み } \\
\end{array}$ & $\begin{array}{l}\text { 肘 } \\
\text { つき }\end{array}$ & $\begin{array}{l}\text { 体 } \rho \\
\text { 傾き } \\
\end{array}$ & \\
\hline カフェ & 0.367 & 0.501 & \begin{tabular}{|c|}
$17-21$ 前栦 \\
0.000 \\
\end{tabular} & 0.397 & 0.673 & $\begin{array}{l}\text { 女前炈 } \\
0.000\end{array}$ & 0.065 & 0.315 & $\begin{array}{r}10 \text { 前䉽 } \\
0.007 \\
\end{array}$ & 0.772 & \begin{tabular}{|c|} 
O*** \\
0.002 \\
\end{tabular} & 0.640 & $\mid 0.196$ & 0.059 & 0.352 & 0.913 & \begin{tabular}{|c|}
$\times *$ \\
0.010 \\
\end{tabular} & 0.225 & $\begin{array}{c}* \\
0.045 \\
\end{array}$ & 0.427 & 0.125 & 0.150 & 0.801 & 0.362 & 女性の比率が高い \\
\hline $\begin{array}{l}\text { ファスㅈ } \\
\text { フード }\end{array}$ & 0.376 & 0.081 & \begin{tabular}{|c|}
$12-17+\frac{+1}{*}$ \\
0.031 \\
\end{tabular} & 0.764 & 0.576 & 0.562 & 0.223 & 0.326 & $\begin{array}{l}40 \text { 垂* } \\
0.047 \\
\end{array}$ & 0.850 & 0.326 & $\begin{array}{l}\text { 又前* } \\
0.020 \\
\end{array}$ & 0.791 & 0,688 & $\begin{array}{l}\text { 前*** } \\
0.002 \\
\end{array}$ & 0.143 & 0.118 & $\begin{array}{l}\text { O前* } \\
0.012 \\
\end{array}$ & 0.625 & 0.250 & $\begin{array}{l}\text { O前* } \\
0.018 \\
\end{array}$ & 0.267 & 0.838 & $\begin{array}{l}\text { O前* } \\
0.388 \\
\end{array}$ & 女前粎： \\
\hline レストラン & \begin{tabular}{|c|}
$12-17 *$ \\
0.016 \\
\end{tabular} & \begin{tabular}{|c|}
$12-17 *$ \\
0.028 \\
\end{tabular} & 0.462 & $\begin{array}{l}\text { 女*** } \\
0.005 \\
\end{array}$ & 0.171 & 0.175 & \begin{tabular}{|c|}
$20 *$ \\
0.041 \\
\end{tabular} & 0.576 & 0.201 & \begin{tabular}{|c|} 
○*** \\
0.001 \\
\end{tabular} & 0.130 & $\begin{array}{l}\times \text { 前* } \\
0.029 \\
\end{array}$ & 0.116 & 0.896 & 0.283 & 0.910 & 0.062 & 0.287 & $\begin{array}{c}\times * \\
0.034 \\
0.03\end{array}$ & 0.507 & 0.120 & 0.060 & \begin{tabular}{|c|}
$\times * *$ \\
0.023 \\
\end{tabular} & 0.081 & \\
\hline 居酒屋 & 0.413 & 0.596 & 0.225 & 0.235 & 0.171 & 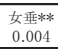 & 0.238 & 0.192 & 0.206 & 0.922 & 0.353 & 0.137 & 0.407 & $\begin{array}{c}* * \\
0.046 \\
\end{array}$ & 0.374 & 0.579 & 0.104 & 0.449 & 0.329 & 0.081 & 0.186 & 0.281 & 0.164 & $\begin{array}{l}\text { O手*** } \\
0.007\end{array}$ & \\
\hline
\end{tabular}


い人よりも肘をつく比率が低くなっている。食事中に肘をつく動作をし にくいことがあること、食事をしていないときに手の置き場に困るこ と、肘をつくことが行儀が悪い動作と捉えられやすいことなどが関って いるのではないかと考えられる。

図6は、勉強と携帯電話の操作の有無と、体の傾きとの関係を示して いる。読書や勉強をしている人はしていない人よりも、前傾姿勢となる 比率が高い。テーブルの上に本や機器を置いて作業することが多いた め、前屈みになりやすいのではないかと考えられる。また、携帯電話を 操作している人は前傾か後傾姿勢の比率が高く、垂直姿勢の比率が低く なっている。テーブルに手をついたり背もたれに寄りかかったりするこ とで、携帯電話を操作しやすくなるためではないかと考えられる。表4 より、これらの傾向は何れもファストフードで顕著であることが分か る。

3-4. 椅子の形状と姿勢との関係

図7は、椅子の背もたれの角度と体の傾きとの関係を示している。背 もたれがない椅子では後傾姿勢をとらないという、椅子の形状に直接起 因する特徴がみられる。ただし、背もたれの角度が90度と90度以上に おいて、体の傾きの違いはあまりみられなかった。これは、背もたれが
90 度以上の椅子でも、ほとんどが100度未満であり、本調査で「後傾」 姿勢に分類される角度以上のものが少なかったからだといえる。また、 背もたれと肘つきとの関係では、表4よりカフェとレストランにおいて 認められており、背もたれのない椅子でテーブルに肘をつく比率が高 かった。こ机は、背もたれがないことで後傾姿勢をとらないことと関係 しているものと考えられる。

図8は、椅子の肘掛の有無と体の傾きとの関係を示している。肘掛が ある椅子では肘掛がない椅子に比べて、垂直姿勢をとる比率が高くなっ ている。肘掛がない椅子では手を膝やテーブルに置くことが多いため、 体もどこかに預けるような姿勢がとりやすくなっているのではないかと 推測できる。

図9は、椅子の座面高さと体の傾きとの関係を示している。座面が低 い椅子は垂直姿勢をとる比率が高く、座面が高い椅子では前傾姿勢をと

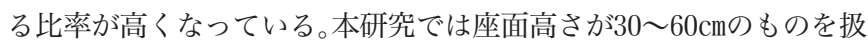
い、極度に高低のあるものは対象としなかった。それでも座面が低い椅 子では、前傾や後傾姿勢が身体的にとりにくかったり、視点が低くなる ために頭を高く上げょうとしたりすることがあるのではないかと推測で きる。
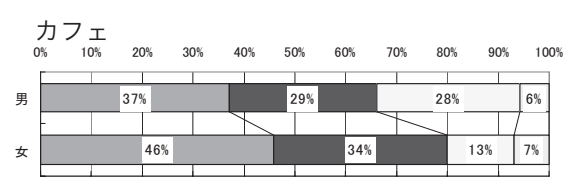

ファストフード

0\% $10 \% \quad 20 \% \quad 30 \% \quad 40 \% \quad 50 \% \quad 60 \% \quad 70 \% \quad 80 \% \quad 90 \% \quad 100 \%$

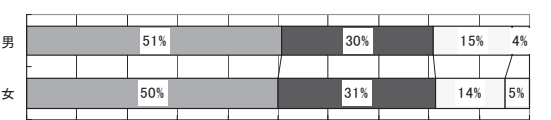

レストラン

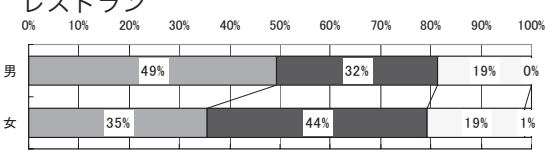

居酒屋

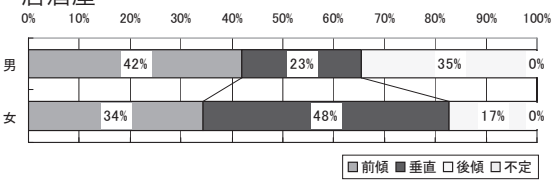

図3性別と体の傾き

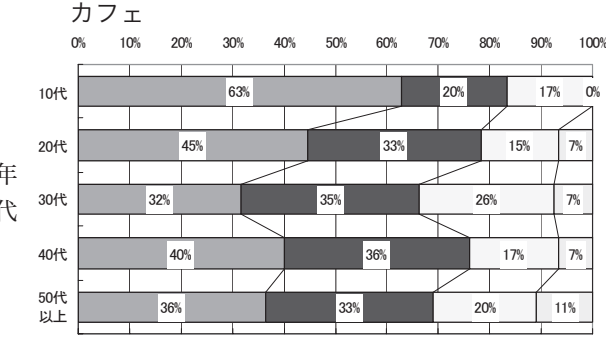

ファストフード

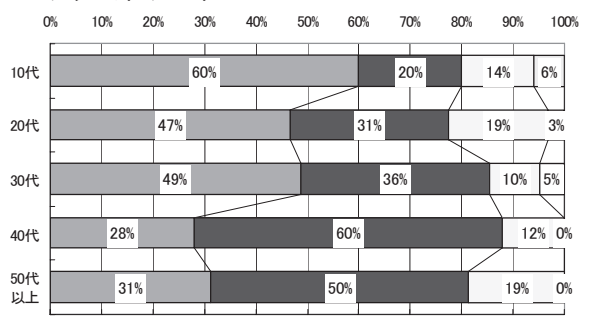

レストラン

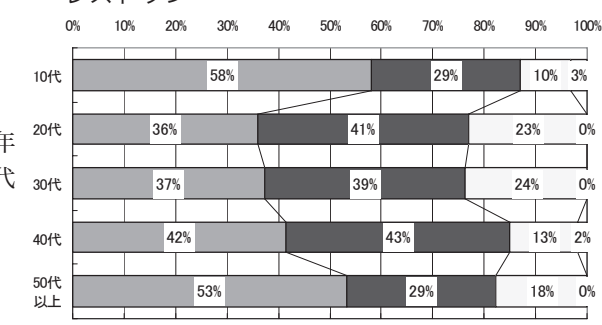

居酒屋

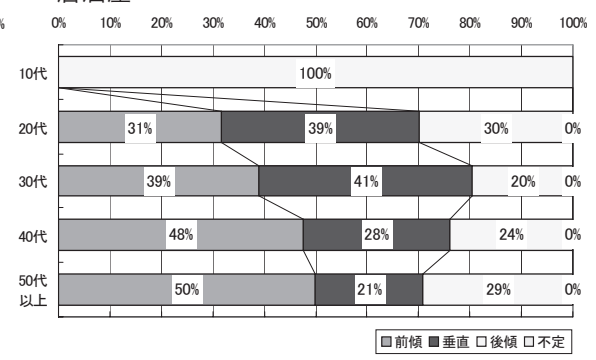

図4利用者の年代と体の傾き

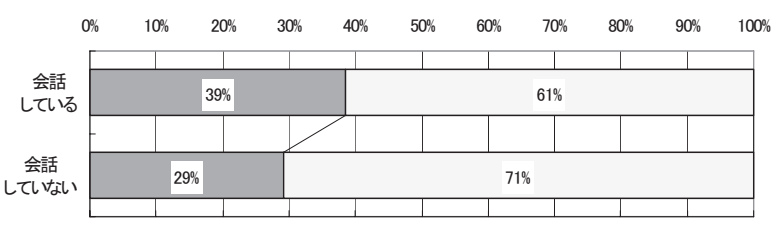

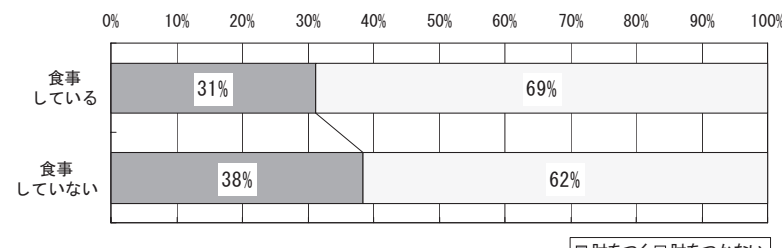

図5 行為の有無と肘つき
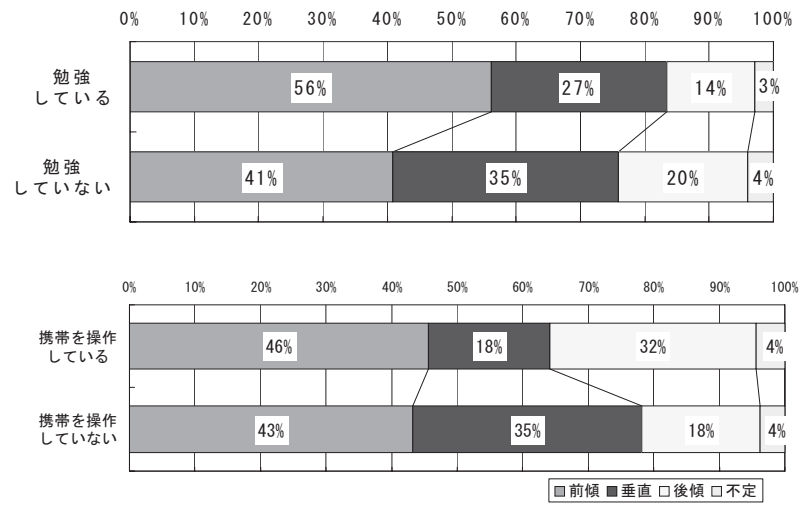

図6 行為の有無と体の傾き 


\section{3-5. 光環境・音環境と姿勢との関係}

図10は、机上面照度と体の傾きの関係を示している。机上面照度が 高い場所ほど、前傾姿勢をとる比率が高くなるという傾向がややみられ ている。顔面照度や周辺照度においても同じ傾向が認められる。筆者ら の既往研究7 ${ }^{711}$ では、低い照度の条件ほど、女性会話者の姿勢が前傾 となる結果が得られており、本研究の結果とは異なっている。ただし、 既往研究 7) では90（1x）と5（lx）の照度条件を比較しており、本研 究の調査サンプルの中では照度が低い部類に入る注4)。うした照度レ ベルの違いが結果の相違に反映しているのではないか推測できる。例え ば、ある明るさのレベルまでは照度が低いときほど互いを良く見ようと 前傾になりやすく、十分に明るいレベルでは高照度になるほど活動的に なって前傾になりやすいことなどがあるのではないかと推測できる。

図11は、周辺音量と肘つきとの関係を示している。周辺音量が小さ い場所での着座者は、音量が「大」や「中」の着座者よりも肘をつく比 率が低くなっている。表4より、レストランでその傾向が顕著である。 座席の周りが静かな場所では、引き締まった印象がしたりして、テーブ ルに肘をつきにくくなることがあるのではないかと推測できる。

図12は、利用者が周囲からの見えやすい位置にいるかどうかと、体 の傾きとの関係を示している。見えやすい位置にいる着座者は見えにく い位置にいる着座者より、垂直姿勢をとる比率が高くなっている。周囲 からの視線にさらされる場所では、背筋を伸ばす姿勢がとられやすいも のと考えられる。

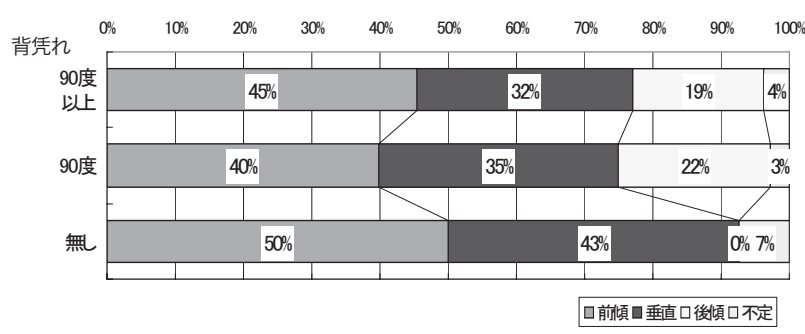

図7背もたれの角度と体の傾き

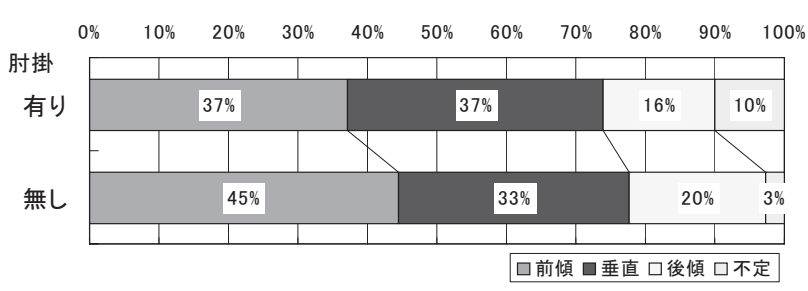

図8 肘掛の有無と体の傾き

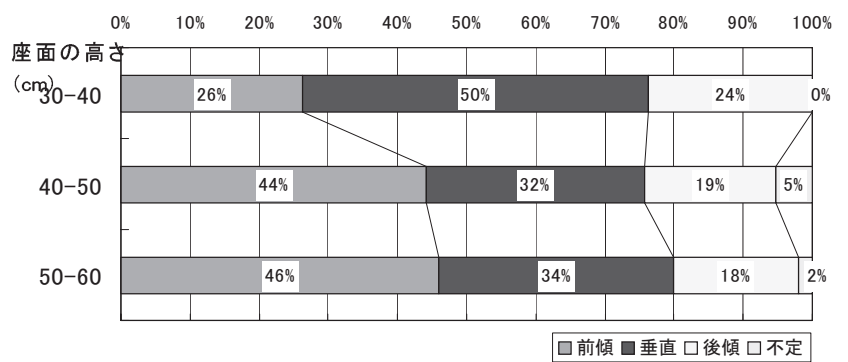

図9＼cjkstart座面の高さと体の傾き
以上のように着座者の姿勢は、性別や年代などの属性、行為、店舗種 別、椅子の形状、光や音環境などとの関係がみられた。またこれらの要 因は相互に影響を与えていたり、コミュニケーションのとり方とも関係 していることが推測されたが、本研究では観察結果のみを基に分析した ため、そうした関係を明確に示すことまではできていない。

\section{4. まとめ}

本研究では、カフェ、ファストフード、レストラン、居酒屋などの飲 食店を利用している着座者の生の姿勢を観察し、その特徴を示すこと と、姿勢のとり方に与える利用者の属性や環境的な要因の影響を探つ た。得られた主な結果を以下に示す。

•調査した1208名の着座者の中で、足を組んでいる比率は全体で約1/ 4であり、肘をついている比率は約1/3であった。体の傾きは前傾が43\%、 垂直が $34 \%$ 、後傾が19\%と、前傾が最も多かった。また男性は女性より 後傾姿勢をとる比率が高かった。

・体の傾きは、ファストフードで前傾の比率が高く、居酒屋で後傾の比 率が高いという特徵があった。レストランと居酒屋では男性の方が前傾 姿勢の比率が高いのに対し、カフェでは女性の方が前傾姿勢の比率が高 いという特徴があった。

•体の傾きは着座者の年代と関係もみられ、ファストフードでは年代が 低いほど前傾姿勢の比率が高く、居酒屋では年代が高いほど前傾姿勢の 比率が高いという傾向がみられた。

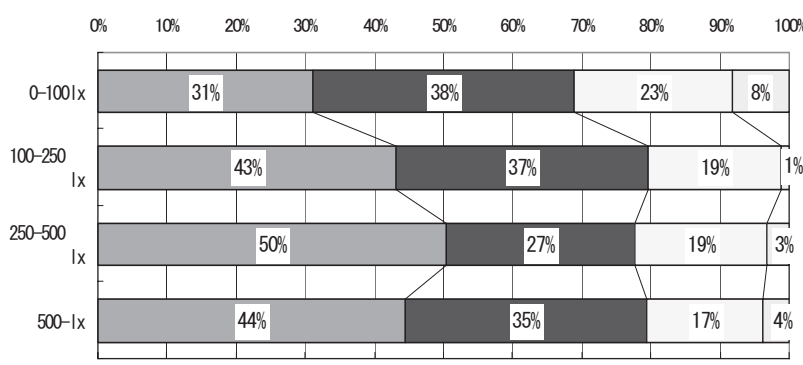

口前傾口垂直口後傾口不定

図10 机上面照度と体の傾き

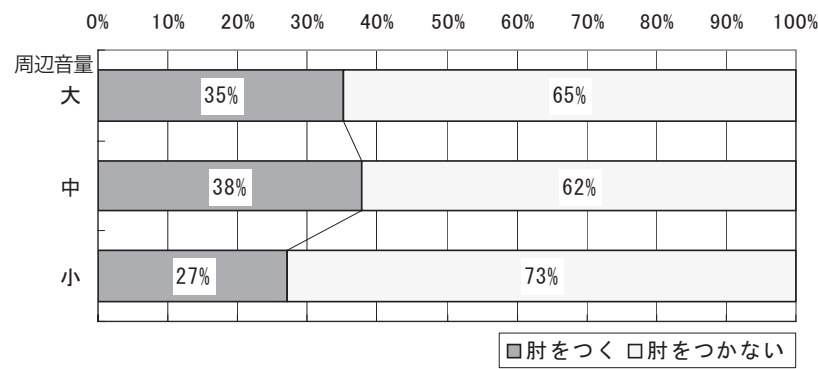

図11周辺音量と肘つき

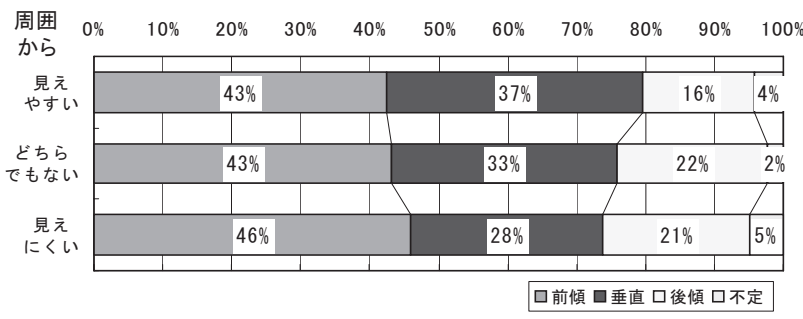

図12 周囲からの見えやすさと体の傾き 
•着座者の行為と姿勢では、会話をしている人は肘をつく比率が高かっ たり、食事をしている人は肘をつく比率が低かったりする傾向がみられ た。

•椅子の形状については、背もたれがない椅子では後傾姿勢をとらない という特徵があり、また肘掛がある椅子では垂直姿勢をとる比率が高い という傾向がみられた。

•机上面照度が高い場所ほど前傾姿勢をとる比率が高く、周辺音量が小 さい場所ほど肘をつく比率が低いという傾向がややみられた。

本研究では飲食店を利用している人々の生の姿勢を観察することとし たため、着座する人々の意識などは把握しておらず、その要因について は推測するに留まっている。今後は、環境条件を統制した実験を行なっ たり、着座者へのインタビューなどによって意識を把握したりすること で、姿勢のとり方に影響する要因を明確にしていきたい。こうした研究 で得られた結果は、特定の姿勢を促したり、あるいはとりにくくさせた りという姿勢の視点から、飲食店の環境を計画をすることに寄与するも のと考えられる。

\section{注}

注 1）カフェとは、コーヒーや紅茶などソフトドリンクの飲み物が主体の飲食店 で、カフェや喫茶店と呼ばれる店舗が含まれる。ファストフードとは、ハン バーガーやサンドイッチ、ドーナツを短時間で食ベられる食品を出す飲食店 で、チェーン店を対象とした。井物や麺類を提供する店舗は含めていない。 カフェは飲み物が主体で、ファストフードは軽食が主体である。レストランは、 食事が中心の飲食店で、注文を取りに来る形式の店舗とした。居酒屋は、 アルコールの提供が中心の飲食店である。ただしカウンターやスタンド形式 でアルコールを提供する、バーやスナックは含めていない。

注 2）調査した店舗は全て、平均的な客単価が 300 円〜 5000 円と思われると ころであり、カジュアルな服装で利用できる場所である。客単価は公表され ている内容と、メニューの調查によって推定した。高級店やフォーマルな店 舗は、観察調査が難しく、十分なサンプル数を集めることができないと判断 したため除外した。

注3）図2の肘つきでは、腕で顔を支えているが、顔や頭を支えていない場合 でも、时をつけていると「肘つき」と判断している。

注 4）もう一方の既往研究 ${ }^{11)}$ は、屋外の昼夜での比較であり、昼間のテーブ 儿面照度は数千 (1x) 以上、夜間のテーブル面照度は30（1x）前後と照度 レベルに大きな開きがある。

\section{参考文献}

1）迫秀樹、河原雅典 : 休憩所における着座姿勢に関する実態調查 若年群 と高年群の比較、静岡文化芸術大学研究紀要、3、pp.85-89、2003.3

2）辻村典久、遠山和延、相澤淳平、山崎信寿：身体の屈曲柔軟性が着座 姿勢に及ぼす影響、人間工学、33、pp.188-189、1997.5

3）小山秀紀、野呂影勇、大津慶子: 椅子の傾斜角度の違いによる座位姿勢 の評価、人間工学、36、pp.572-573、2000.6

4）岩切一幸、毛利一平、外山夕どり、野瀬がり、落合孝則、城内博、斉 藤進 : フリーアドレス形式オフィスレイアウトでのVDT作業者の姿勢および身 体的疲労感、産業衛生学雑誌、48(1)、pp.7-14、2006.1

5）渡辺秀俊、安藤正雄、高橋鷹志：着座場面における姿勢の経時的変化 人間 - 環境系における着座姿勢の働態に関する研究(第 1 報)、日本建築 学会計画系論文集、No.474、pp.107-114、1995.8

6）日下部真世、長澤夏子、渡辺仁史 : 食事姿勢加見たしつらいの違いと 時間経過に関する研究、日本建築学会学術講演梗概集建築計画 I、 pp.751-752、2006.7

7）小林茂雄、小口尚子 : カフェでの会話行動に及ぼす照度とBGM 音量の影 響、日本建築学会環境系論文集、No.605、pp.119-125、2006.7

8）小林茂雄、小口尚子 : 対人状況と光環境に応じた室内音環境の適性 会 話場面での周囲音圧レベルの最適值と許容值に関する研究、日本建築学会 環境系論文集、No.589、pp.59-65、2005.3

9）小林茂雄、吉崎圭介 : 室内不均一照明下での会話者の位置選択に関する 研究、日本建築学会計画系論文集、No.562、pp.83-88、2002.12

10) 小林茂雄: 室内不均一照明下でとられる会話行動の属性別特徵 カフェを 想定した室内での会話者の行動と意識に関する検討、日本建築学会環境系 論文集、No.574、pp.15-20、2003.12

11）小林茂雄、吉崎圭介 : 昼夜のオープンテラスでとられる会話行動の属性別 特徵 夏期の新宿アイランドパティオを対象にしたケーススタディ、日本建築 学会環境系論文集、No.571、pp.69-74、2003.9

12）小島雅子: 光源とそのとりまく要因が室内雾囲気に及ぼす影響、家政学研 究、Vol.34, No.1、pp.69-77、1987.09

(2008年 5 月 27 日原稿受理，2008年 8 月29日採用決定） 